\begin{abstract}
"AB TRASCENDENT E VISCERAL GOTG E PROFUNDA ALEGRIA": LAS CELEBRACIONES POR LA ENTRADA DE FERNANDO I DE ARAGÓN EN VALENCIA (1414)

"AB TRASCENDENT E VISCERAL GOTG E PROFUNDA ALEGRIA": THE CELEBRATIONS FOR THE ROYAL ENTRY OF FERNANDO I DE ARAGÓN INTO VALENCIA (1414)
\end{abstract}

\title{
Francesc ORTS-RUIZ
}

http://doi.org/10.7203/arslonga.28.13701

Resumen: La entrada de Fernando I en Valencia supuso un punto de inflexión en el desarrollo de los recibimientos regios en la ciudad. Tras el interregno y el compromiso de Caspe, el primer representante de la casa de Trastámara en la Corona de Aragón hizo su primera visita a un municipio que, en un primer momento, fue contrario a su candidatura. Este hecho se vio reflejado en las celebraciones que se realizaron en 1414, y fue el principal motivo por el que diferentes cambios y novedades tuvieron lugar, aunque sin perder de vista la tradición. Dedicaremos este artículo a analizar esta entrada, reconstruyendo, a través de la documentación de época, su desarrollo e influencia en celebraciones posteriores.

Palabras clave: Entradas reales / Corona de Aragón / Fernando I / fiesta urbana / arte efímero.

\begin{abstract}
The royal entry of Fernando I into Valencia supposed a turning point in the development of the royal receptions in the city. After the interregnum and the compromise of Caspe, the first representative of the house of Trastámara in the Crown of Aragon made his first visit to a municipality that, at first, was contrary to his candidacy. This fact was reflected in the celebrations that took place in 1414 and it was the main reason why different changes and novelties took place, although without forgetting the tradition. We will dedicate this article to analyse this entry, reconstructing, through the original documentation, its development and influence in later celebrations.
\end{abstract}

Key words: Royal entries / Crown of Aragon / Fernando I / urban celebrations / ephemeral art.

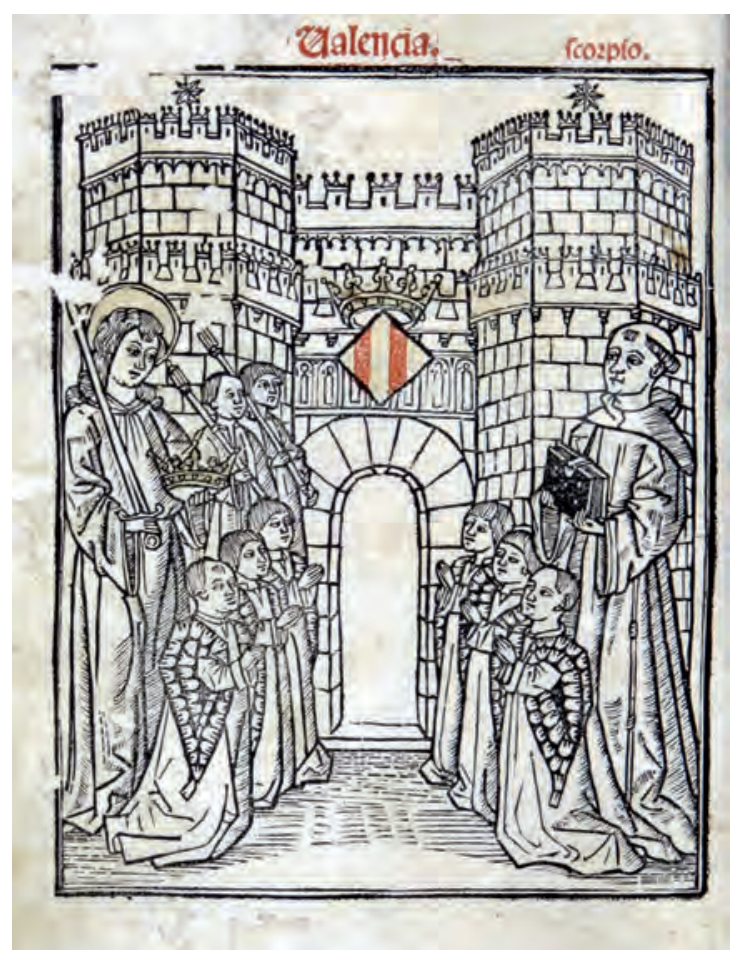


LA ESCUELA PICTÓRICA DE AMBERES EN LA SEGUNDA MITAD DEL SIGLO XVI EN BURGOS. LA ESTELA DE FRANS FLORIS A TRAVÉS DE DOS OBRAS DE SUS DISCíPULOS: CRISPIJN VAN DEN BROECK Y FRANS POURBUS I

THE PICTORIAL SCHOOL OF ANTWERP IN THE SECOND HALF OF THE 16TH CENTURY IN BURGOS. THE WAKE OF FRANS FLORIS THROUGH TWO WORKS OF HIS DISCIPLES: CRISPIJN VAN DEN BROECK Y FRANS I POURBUS

\section{Ana DIÉGUEZ RODRÍGUEZ \& René Jesús PAYO HERNANZ}

http://doi.org/10.7203/arslonga.28.14519

Resumen: Crispijn van den Broeck y Frans Pourbus I fueron dos pintores flamencos discípulos de Frans Floris. Su actividad artística se desarrolló en la segunda mitad del siglo XVI. Lograron gran fama y sus obras fueron exportadas a muchos países Europeos. En Burgos se conservan dos interesantes pinturas sobre tabla: Un Juicio Final de Crispijn van den Broeck y un San Jerónimo de Frans Pourbus I que llegaron a esta ciudad gracias a las relaciones comerciales entre Castilla y Flandes.

Palabras clave: Crispijn van den Broeck / Frans Pourbus I / Frans Floris / Amberes / Burgos / Pintura Flamenca / segunda mitad del siglo XVI / Juicio Final / San Jerónimo.
Abstract: Crispijn van den Broeck and Frans I Pourbus were two Flemish painters disciples of Frans Floris. Their artistic activity was developed in the second half of the 16th century. They achieved great fame and their works were exported to many European countries. In Burgos there are two interesting paintings: a Final Judgement by Crispijn van den Broeck and a Saint Jerome by Frans I Pourbus both brought to this city thanks to the trade relations between Castile and Flanders.

Key words: Crispijn van den Broeck / Frans I Pourbus / Frans Floris / Antwerp / Burgos / Flemish Painting / second half of the 16th century / Final Judgement / Saint Jerome.

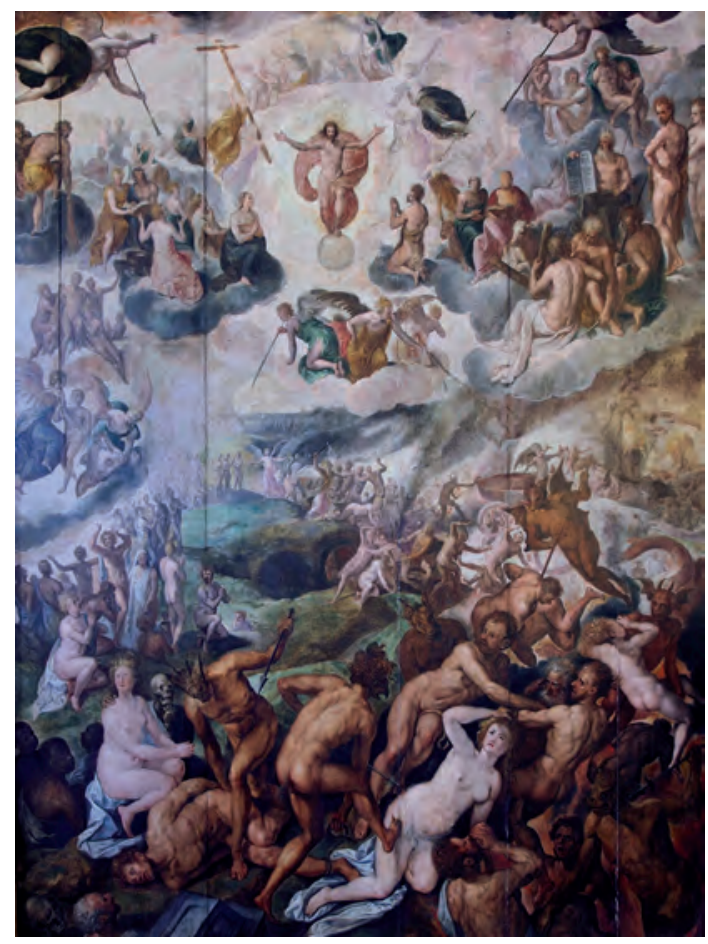


EL RETABLO DE SAN AGUSTÍN DE VALENCIA, OBRA DE MIGUEL DEL PRADO (1521)

THE ALTARPIECE OF SAN AGUSTIN OF VALENCIA, BY MIGUEL DEL PRADO (1521)

\section{Mercedes GÓMEZ-FERRER LOZANO}

http://doi.org/10.7203/arslonga.28.13786

Resumen: Este estudio confirma la autoría del pintor Miguel del Prado (+1521) a partir de documentación inédita para unas tablas que pertenecieron a un retablo realizado para el convento de San Agustín de la ciudad de Valencia conservadas en el Museo de Bellas Artes de Valencia y en el Lazaro Galdiano de Madrid. Se certifica así la personalidad de Miguel del Prado, puesta en entredicho y se confirma un corpus de pinturas, entre las que se incluye también el retablo de San Vicente para el convento dominico de Museros y otra serie de trabajos.

Palabras clave: Miguel del Prado / pintura renacentista / retablos / Valencia / convento de San Agustín.
Abstract: By means of a new documentary evidence, this text confirms the authorship of the painter Miguel del Prado (+1521) for a series of paintings that once belonged to a retable of the Augustinian convent of the city of Valencia, nowadays in the Arts Museum of Valencia and the Lazaro Galdiano Museum in Madrid. We analyse the personality of this painter, which has been controversial and confirm a corpus of paintings, that include the Saint Vicent retable for the dominican convent of Museros, among others.

Key words: Miguel del Prado / renaissance paintings / retables / Valencia / Saint Augustin convent. 
DE PIEDRA NEGRA, TINTA AGUADA Y ALBAYALDE. LAS TÉCNICAS DE DIBUJO DE JOAN DE JOANES Y EL 'ESTADO DEL ARTE' EN LA VALENCIA DEL SIGLO XVI. ¿TRADICIÓN O INNOVACIÓN?

WITH BLACK PENCIL, INK WASHES AND WHITE LEAD HIGHLIGHTS. DRAWING TECHNIQUES BY JOAN DE JOANES AND THE STATE OF THE ART OF DESIGN IN VALENCIA IN THE 16TH CENTURY. TRADITION OR INNOVATION?

\section{Miquel A. HERRERO-CORTELL \& Isidro PUIG SANCHIS}

http//doi.org/10.7203/arslonga.28.14390

Resumen: El artículo pretende realizar un somero análisis al corpus de dibujos sobre papel atribuido a Joan de Joanes y a sus más directos seguidores, desde una óptica metaformal, adentrándose en la génesis de esos diseños, desde su concepción hasta sus funciones. Han sido muy eventuales las apreciaciones sobre los procedimientos gráficos usados por el pintor $y_{\text {, }}$ en general, la cuestión de sus dibujos se ha abordado siempre desde la tradicional perspectiva de confrontación iconográfica y formal. No se ha ahondado en cuestiones que, creemos, resultan claves para entender una figura tan poliédrica y compleja: como cuánto débito existe entre el ductus gráfico de Joanes y el de su padre, y qué relación guarda con la tradición hispana; o hasta qué punto puede ser la visualización de modelos y estampas italianas la responsable de su marcado italianismo. Una revisión que incide en la técnica y en la elección procedimental como una vía de ida y vuelta para explicar los vínculos entre su dibujo y su metodología pictórica (más allá de la superficial apariencia). Son de aspectos que, en última instancia, hunden sus raíces en la praxis pictórica y en los rudimentos del oficio; en los mecanismos de trabajo del obrador y su funcionamiento; asuntos como la fijación de modelos o el uso de procedimientos mecánicos de seriación.

Palabras clave: dibujos / Joan de Joanes / procedimientos gráficos / papel / Renacimiento.
Abstract: The paper intends to make a brief analysis of the corpus of drawings on paper attributed to Joan de Joanes and his most direct followers, from a metaformal approach, going into the very genesis of such designs, from their conception to their functions. There are very few references about the graphic procedures used by the painter and, in general, the question of his drawings has always been approached from the traditional perspective of iconographic and formal confrontation. There is an evident lack of deepening in questions that, in our opinion, are key to understanding a such complex figure. How much debit is there between the graphic ductus of Joanes and that of his father? And what relationship does it have with the Hispanic tradition? To what extent can it be the display of Italian models and prints responsible for its marked Italianism? A revision devoted to technique and the procedures is done to explain the links between his drawing and his pictorial methodology (beyond the superficial appearance). These are aspects that have their roots in the pictorial praxis and in the rudiments of the job. They constitute the working mechanisms of the workshop. The article intends to deal with issues such as the fixation of models or the use of mechanical procedures of transferring.

Key words: drawings / Joan de Joanes / graphic procedures / paper / Renaissance.
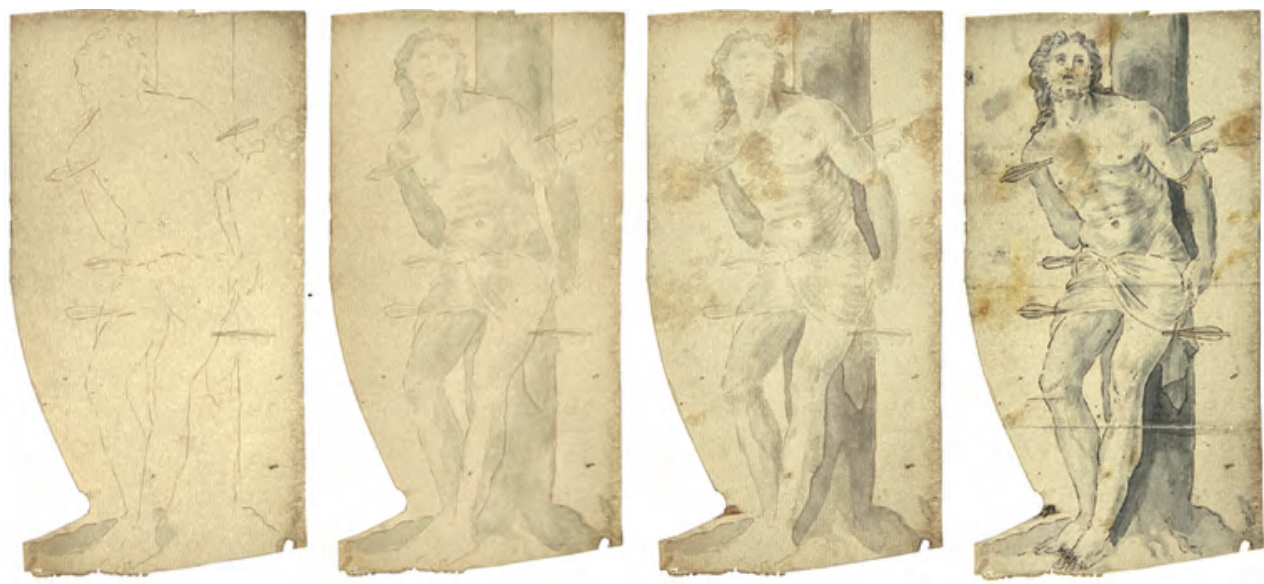


\begin{abstract}
ARQUITECTURA PARA DOS CARISMAS DISTINTOS EN EL BAJO ARAGÓN TUROLENSE EN EL SEISCIENTOS: EL CONVENTO CARMELITA DE ALCAÑIZ Y EL DESCALZO DEL DESIERTO DE CALANDA

ARCHITECTURE MADE FOR TWO TYPES OF CHARACTER IN THE 17TH CENTURY TERUEL'S BAJO ARAGÓN: THE CARMELITES CONVENT IN ALCAÑIZ AND THE CARMELITES DISCALCED ONE IN THE DESERT OF CALANDA
\end{abstract}

\title{
Jorge MARTÍN MARCO
}

http://doi.org/10.7203/arslonga.28.14654

Resumen: En el Bajo Aragón turolense se asentaron un gran número de órdenes religiosas en las primeras décadas del Seiscientos, y entre ellas, los carmelitas, que Ilegaron a Alcañiz en 1602; y los carmelitas descalzos, que se establecieron en el convento del desierto de Calanda en la década de los ochenta de ese siglo. Sin embargo, las diferencias entre ambos establecimientos son evidentes, ya que fueron concebidos tanto espiritual como arquitectónicamente diferentes uno de otro debido a las funciones que debían cumplir. El caso alcañizano es una de las muestras más destacadas de la arquitectura bajoaragonesa del barroco, mientras que el calandino es un buen ejemplo de desierto carmelita, cuyas trazas probablemente fueron realizadas por artífices de la orden.

Palabras clave: Arquitectura barroca / Carmelitas / Trazas / Bajo Aragón / Alcañiz / Calanda.
Abstract: A great number of religious orders settled in the Bajo Aragón in Teruel in the first decades of the 17th century, among them the Carmelites that arrived in Alcañiz in 1602; or the Carmelites Discalced, that settled in the convent of the desert of Calanda in the decade of the 80 s of that century. However, the differences between both establishments are evident, since they were conceived differently both spiritually and architecturally due to the different function that they had to fulfil. In the case of Alcañiz, it is one of the most prominent samples of the architecture of the Bajo Aragón in the Baroque period, while in Calanda's case, it is a good example of Carmelite desert, the design of which was probably made by authors of the order.

Key words: Baroque architecture / Carmelites / Traces / Bajo Aragón / Alcañiz / Calanda.

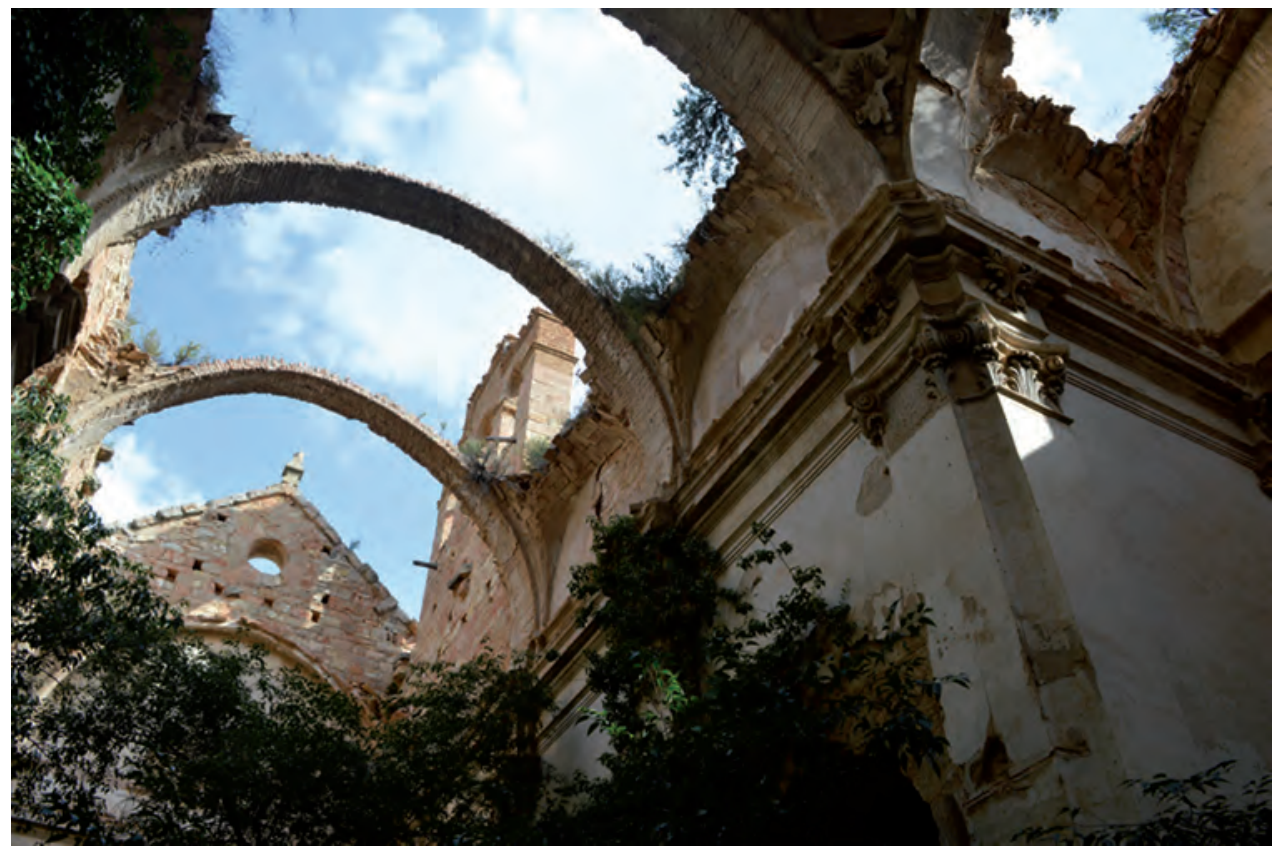


LOS III CONDES DE MIRANDA Y SUS FUNDACIONES RELIGIOSAS: ENTRE EL RECUERDO FAMILIAR Y LA EXALTACIÓN DEL LINAJE

THE III COUNTS OF MIRANDA AND THEIR RELIGIOUS FOUNDATIONS: BETWEEN FAMILY MEMORIES AND LINEAGE EXALTATION

\section{Juan ESCORIAL ESGUEVA}

http://doi.org.10.7203/arslonga.28.13794

Resumen: Francisco de Zúñiga y Avellaneda, III conde de Miranda, y su esposa, María Enríquez de Cárdenas, desarrollaron, a lo largo del primer tercio del siglo XVI, un importante conjunto de actuaciones entre las cuales, sus fundaciones religiosas, destacan de forma especial. Las distintas promociones que el matrimonio llevó a cabo en la villa burgalesa de Peñaranda de Duero y el cercano monasterio de Santa María de La Vid, donde se ubicaría su sepultura, contribuyeron a definir la imagen con la que se quería identificar al linaje.

Palabras clave: condes de Miranda / arquitectura / Burgos / siglo XVI / Renacimiento.
Abstract: Francisco de Zúñiga y Avellaneda, 3rd count of Miranda, and his wife, María Enríquez de Cárdenas, developed, during the first third of the 16th century, an important set of activities among wich their religious foundations stand out in a special way. The different promotions that the marriage carried out in Peñaranda de Duero (Burgos) and the construction of the main chapel of the monastery of Santa María de La Vid, where their grave would be located, contributed to define the new image with which they wanted to identify their lineage.

Key words: counts of Miranda / architecture / Burgos / 16th century / Renaissance.

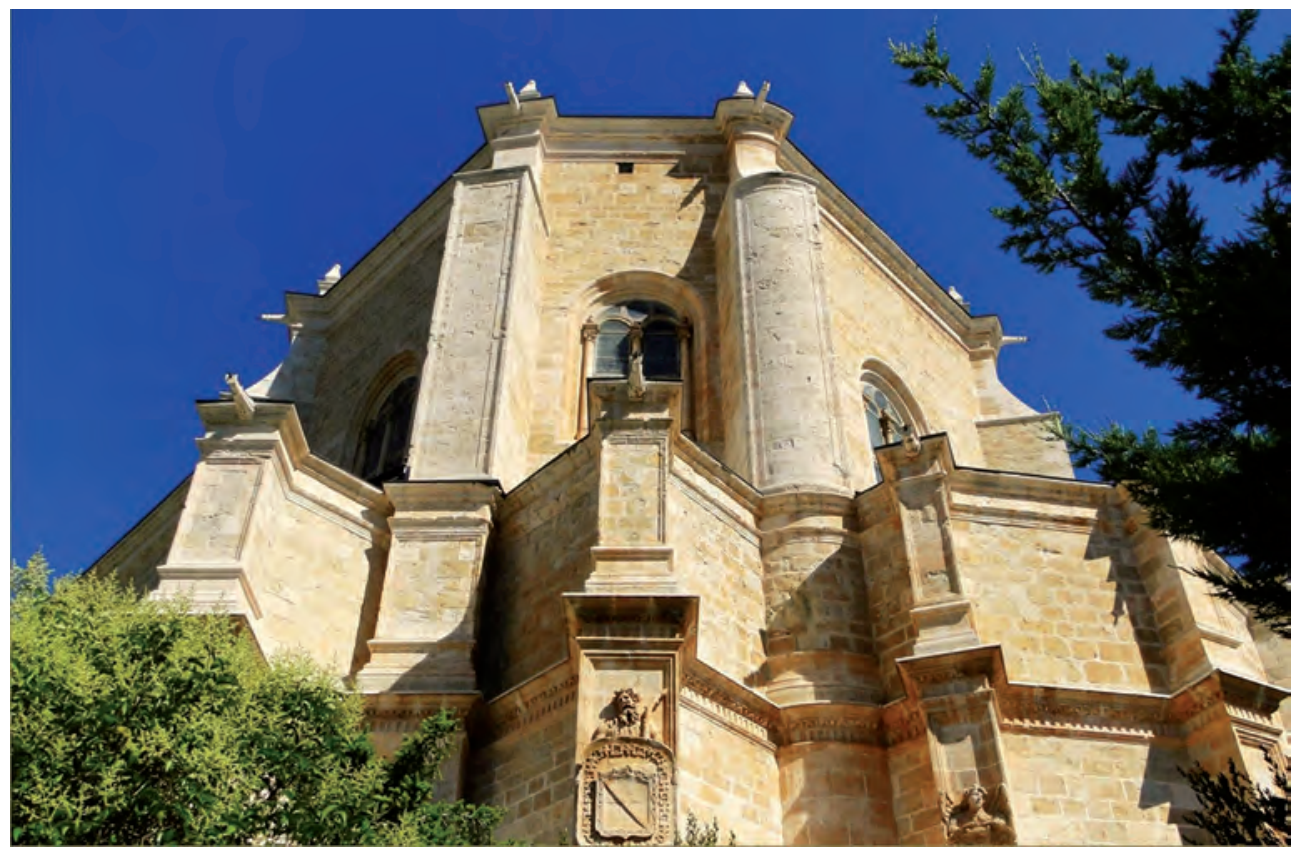




\section{BIENES Y ESPACIOS DE PRIVANZA EN EL CASTILLO Y PALACIO DEL DUQUE DE LERMA EN DÉNIA \\ GOODS AND SPACES OF FAVORITISM IN THE CASTLE AND PALACE OF THE DUQUE OF LERMA IN DÉNIA}

\section{Àngel CAMPOS-PERALES}

http://doi.org/10.7203/arslonga.28.14524

Resumen: Francisco Gómez de Sandoval y Rojas (1553-1625), V marqués de Dénia y I duque de Lerma, emprendió una importante transformación de su palacio valenciano de Dénia desde no mucho antes de 1611 y hasta los comienzos de los años 20 del siglo XVII. Las reformas constructivas y las labores de equipamiento de la casa, que se intensificaron entre 1616 y 1618 , estuvieron destinadas a dar alojamiento digno al rey Felipe III en la frustrada visita real a Dénia para la celebración de Cortes del Reino de Valencia. Así, a partir de una vista desconocida de Dénia y documentación de archivo inédita pretendemos redefinir las cronologías de unas arquitecturas prácticamente desaparecidas y poco estudiadas, reconstruir los espacios que las conformaban y determinar la sistematización de bienes que se custodiaron en su interior y exterior.

Palabras clave: duque de Lerma / Felipe III / castillo de Dénia / pintura / Juan de Chavarria / Carlos Coloma / mesas de piedras duras.
Abstract: Francisco Gómez de Sandoval y Rojas (1553-1625), V Marquis of Dénia and I Duke of Lerma, undertook an important transformation of his Valencian palace in Dénia from not long before 1611 and until the beginning of the 20's of the 17th century. The construction reformations and the equipping of the palace, which intensified between 1616 and 1618, were designed to provide a dignified accommodation for King Philip III in the frustrated royal visit to Dénia for the celebration of Cortes of the Kingdom of Valencia. Thus, from an unknown view of Dénia as well as unpublished archive documentation, we intend to redefine the chronologies of these practically disappeared architectures, reconstruct the spaces that configured them and determine the systematization of goods that were guarded inside and outside.

Key words: Duke of Lerma / Philip III / castle of Dénia / painting / Juan de Chavarria / Carlos Coloma / hardstone tabletops.

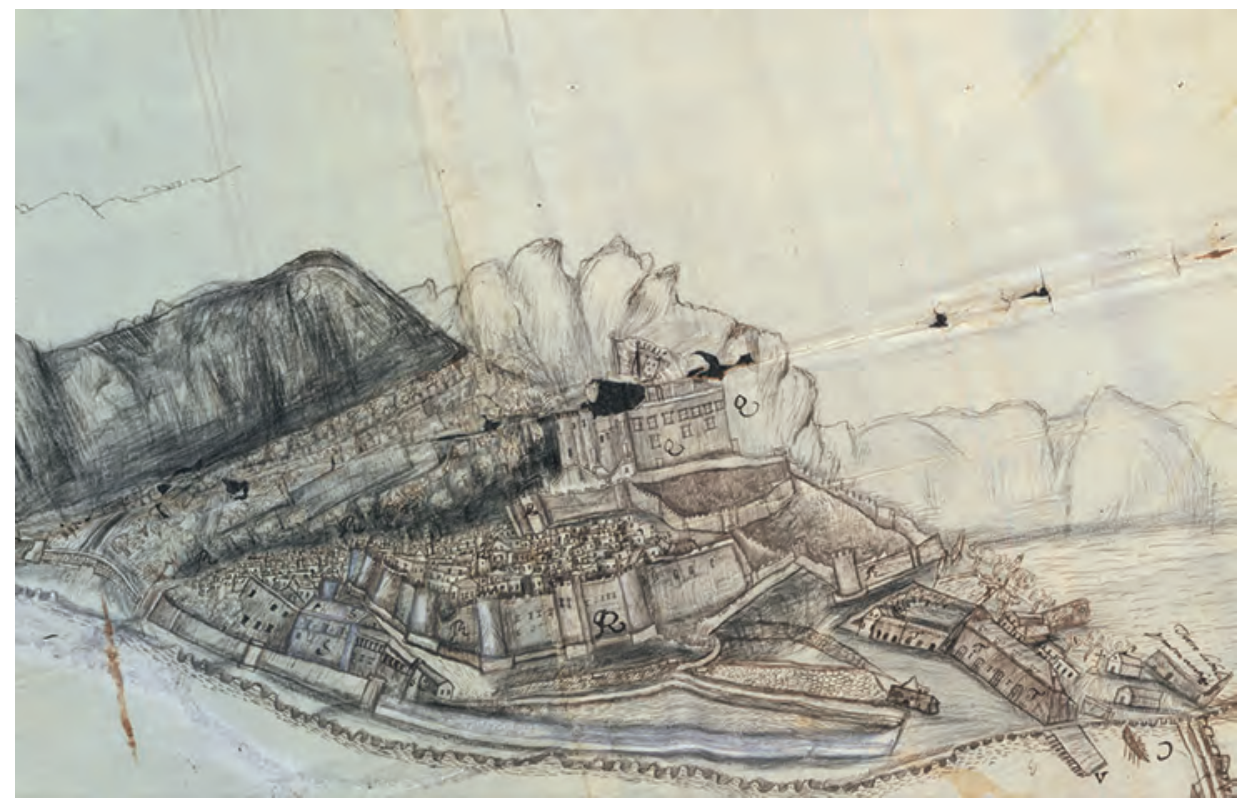


EL ALBAÑIL JOSÉ URBISO Y SU DECISIVA CONTRIBUCIÓN A LA CONSTRUCCIÓN DE LA IGLESIA DEL COLEGIO DE LA COMPAÑÍA DE JESÚS DE CALATAYUD

THE CRAFTMEN JOSÉ URBISO AND HIS DECISIVE CONTRIBUTION TO THE CONSTRUCTION OF THE CHURCH OF THE SOCIETY OF JESUS COLLEGE IN CALATAYUD

\section{David Miguel NAVARRO CATALÁN \& Naike MENDOZA MAEZTU}

http://doi.org/10.7203/arslonga.28.13294

Resumen: La iglesia del colegio de la Compañía de Jesús de Calatayud presenta un dilatado proceso constructivo y decorativo que abarca del siglo XVII al XVIII. Se profundiza en las diferentes fases históricas aportando documentación inédita en la que destaca la capitulación de la nave de la iglesia con el albañil José Urbiso. En sus obras intervienen numerosos artífices entre los que se incluye un grupo de miembros de la Compañía cuya actividad era ignorada hasta el momento como la del hermano José Iraola. Además, el descubrimiento del proyecto redactado por el hermano Antonio Ambrosio contribuye a incrementar el conocimiento de nuevos arquitectos miembros de la Compañía en el ámbito de la antigua provincia jesuita de Aragón.

Palabras clave: Calatayud / jesuitas / Urbiso / Ambrosio / barroco / Aragón.
Abstract: The church of the Society of Jesus college in Calatayud presents an extensive constructive and decorative process that takes from the 17th to the 18th century. This article goes in depth into its different historical phases revealing unpublished documentation, such as the contract for the church's nave with the mason José Urbiso. A great number of craftsmen intervened in its works, including a group of the Company members, whose activity was ignored until now like brother's José Iraola. Additionally, the discovered project elaborated by brother Antonio Ambrosio contributes to increase the knowledge of new architects that were Company members in the sphere of the old Jesuit province of Aragon.

Key words: Calatayud / Jesuits / Urbiso / Ambrosio / Baroque / Aragón.

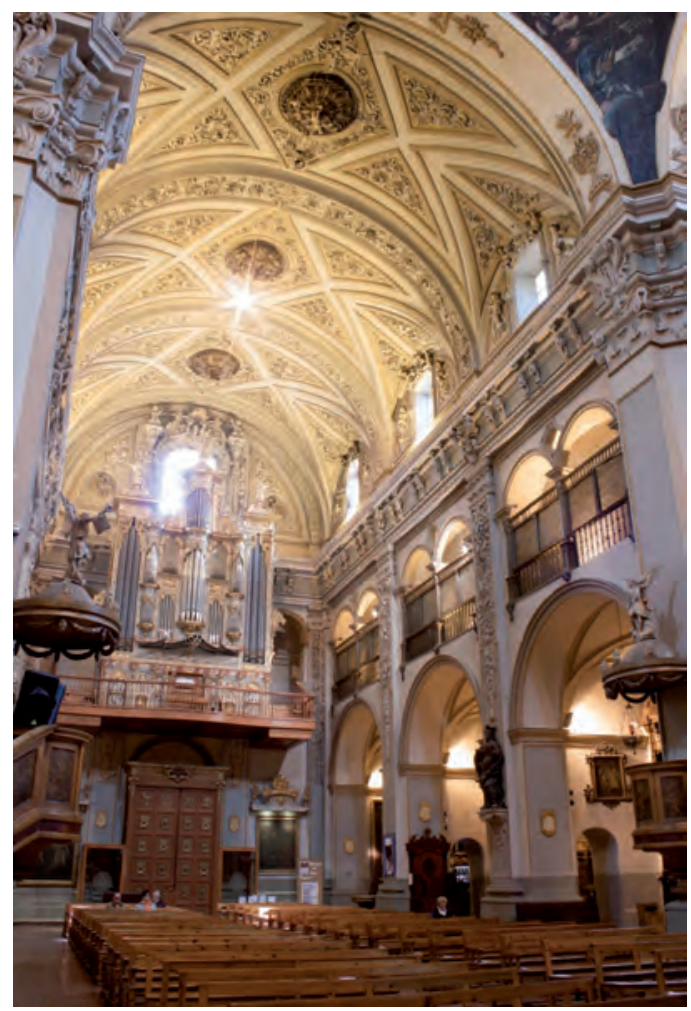


UN RETABLO DE ÁNIMAS DE POSIBLE ORIGEN VALENCIANO EN VILLARROYA DE LA SIERRA (ZARAGOZA)

A RETABLO DE ÁNIMAS OF POSSIBLE VALENCIAN ORIGIN IN VILLARROYA DE LA SIERRA (ZARAGOZA)

\section{Jesús CRIADO MAINAR}

http://doi.org/10.7203/arslonga.28.14342

Resumen: El artículo da a conocer el retablo de almas de la iglesia parroquial de la localidad de Villarroya de la Sierra (Zaragoza), un conjunto barroco configurado entre 1672 y 1674 en el que se incluyó una magnífica pintura sobre tabla de cronología anterior (hacia 1520-1527) para la que aquí proponemos un origen valenciano y que ya formaba parte del ajuar litúrgico del templo en 1607 , si bien pensamos que pudo llegar al mismo en una fecha anterior.

Palabras clave: Retablos de almas / arte renacentista / iconografía / circulación de obras de arte.
Abstract: The article reveals the altarpiece of souls of the parish church of the village of ViIlarroya de la Sierra (Zaragoza), a Baroque ensemble set between 1672 and 1674 where a magnificent painting was included on the previous chronological table (towards 1520-1527) for which here we propose a Valencian origin and which was already part of the liturgical trousseau of the temple in 1607, although we think that it could reach it at an earlier date.

Key words: Altarpieces of souls / Renaissance art / iconography / circulation of works of art.

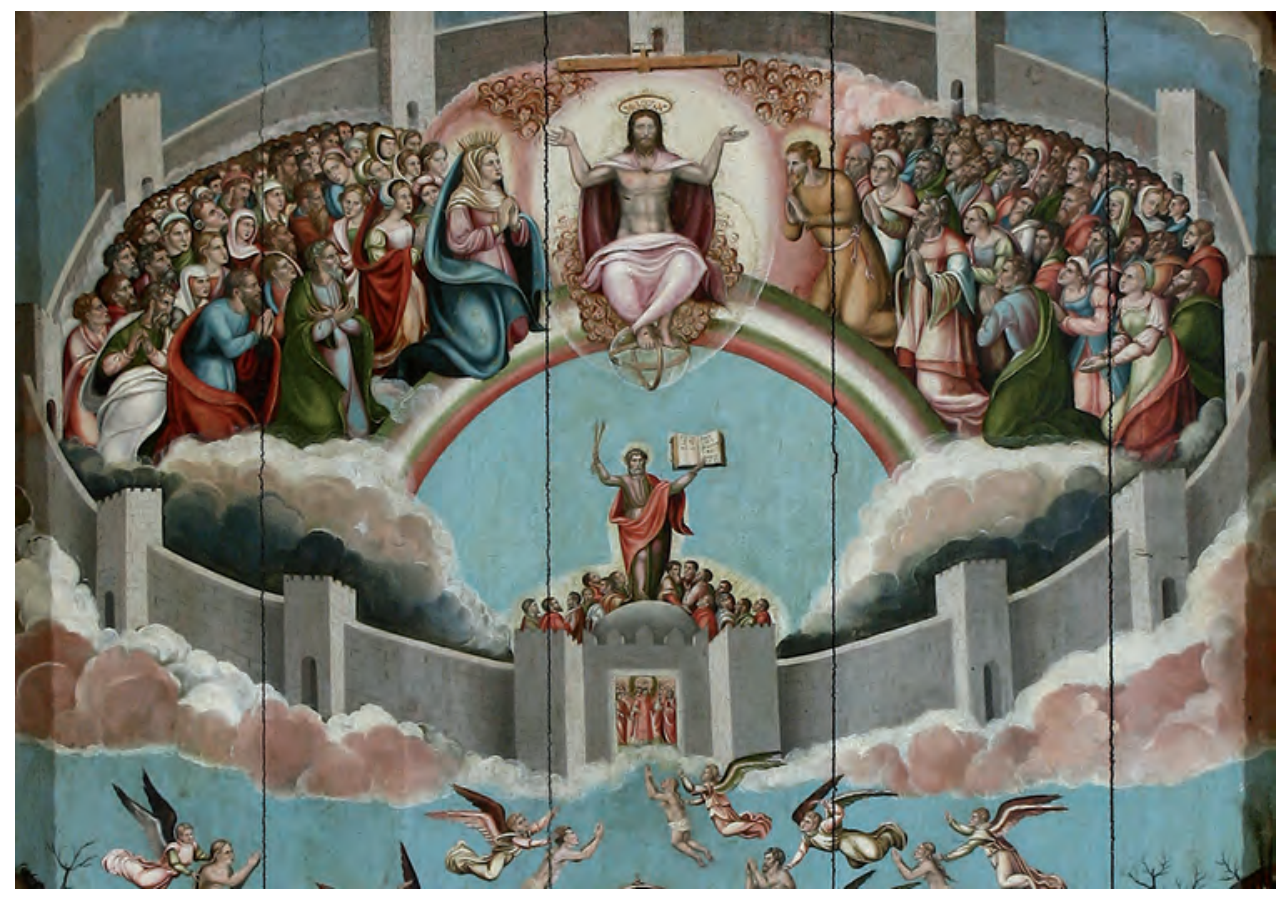


LAS ALHAJAS Y ORNAMENTOS LITÚRGICOS DE LA CAPILLA DE LOS DUQUES DE MONTEMAR EN LA BASÍLICA DEL PILAR DE ZARAGOZA

JEWELRY AND THE LITURGICAL TROUSSEAU OF THE CHAPEL OF THE DUKES OF MONTEMAR IN THE BASILICA OF OUR LADY OF THE PILLAR OF SARAGOSSA

\section{María Josefa TARIFA CASTILLA}

http://doi.org/10.7203/arslonga.28.14250

Resumen: El presente artículo da a conocer y estudia el ajuar litúrgico proporcionado por María Magdalena Carrillo de Albornoz, II duquesa de Montemar, para la capilla de patronato que poseía desde 1761 en la Basílica de Pilar de Zaragoza bajo la titularidad de San Joaquín. Esta aristócrata dotó la capilla con los ornamentos textiles y piezas de orfebrería necesarios para el servicio del culto, como refieren los inventarios de 1789, 1804 y 1873. Entre las alhajas de plata destacaban un cáliz renacentista y un relicario barroco con las armas de los Montemar, que han sido localizados en la sacristía mayor del mismo templo del Pilar.

Palabras clave: Duques de Montemar / Basílica de Nuestra Señora del Pilar / Zaragoza / siglo XVIII / platería / ornamentos litúrgicos.
Abstract: This article deals with the study of the liturgical trousseau provided by Maria Magdalena Carrillo de Albornoz, II Duchess of Montemar, for the patronage chapel of saint Joachim she had owned since 1761 in the Basilica of Our Lady of the Pillar of Saragossa. This aristocrat endowed the chapel with the textile ornaments and pieces of goldsmithing necessary for the service of the cult, as it's referred in the inventories of 1789, 1804 and 1873. Among the silver jewels stood out a Renaissance chalice and a baroque reliquary with the coat of arms of the Montemar, which are located in the main sacristy of the same temple of Pillar.

Key words: Dukes of Montemar / Basilica of Our Lady of the Pillar / Saragossa / 18th century / silverwork / liturgical clothes. 


\section{LA PLATERÍA EN LA BASÍLICA DE ALGEMESÍ (SS. XVI-XX) \\ THE SILVERWARE AT THE BASILICA OF ALGEMESÍ (16TH TO 20TH CENTURY)}

\section{Francisco de Paula COTS MORATÓ}

http://doi.org/10.7203/arslonga.28.14580

Resumen: El presente artículo estudia la colección de plata de la Basílica de Algemesí (La Ribera Alta), formada por piezas cuya cronología abarca desde el siglo XVI al XX. Se indican las dataciones de las obras de esta colección y sus marcas, asignándolas al obrador correspondiente. Las más importantes fueron labradas en los siglos XVI y XVIII, aunque también se realizan obras de platería en otras centurias.

Palabras clave: Algemesí / platería / marcas / ajuar litúrgico / Arte Valenciano.
Abstract: The silverware collection of the Basilica of Algemesí (La Ribera), formed by works dating from the 16th to the 20th century, was studied. The different items (of the collection) were dated and their marks were assigned to the respective workshops. The most important pieces were produced in the 16th century and the 18th century, although additional silverware was also commissioned in other centuries.

Key words: Algemesí / silverware / marks / liturgical objects / Valencian Art. 


\section{RELACIONES VISUALES ENTRE LA PRUDENCIA Y LAS VIRTUDES QUE LA COMPONEN VISUAL RELATIONS BETWEEN PRUDENCE AND THE VIRTUES THAT COMPOSE IT}

\section{María MONTESINOS CASTAÑEDA}

http://doi.org/10.7203/arslonga.28.14663

Resumen: La Prudencia, como una de las Virtudes Cardinales, ha sido dividida por los pensadores en diferentes partes, las cuales exponen y especifican los objetivos y funciones de esta virtud. La imagen de la Prudencia se traduce en una alegoría portadora de diferentes atributos que constituyen la propia visualización de sus partes. Asimismo, muestra conexiones visuales con la imagen de la Prudencia.

Palabras clave: Prudencia / Iconografía / Virtudes Cardinales / Alegorías.
Abstract: Prudence, like one of the Cardinal Virtues, has been divided by the thinkers in different parts, which expose and specify the objective and functions of this virtue. Prudence's image is translated in an allegory that carries different attributes which constitute the own visualization of its parts. Likewise, the visualization of Prudence's parts shows visual connections with Prudence's image.

Key words: Prudence / Iconography / Cardinal Virtues / Allegories.

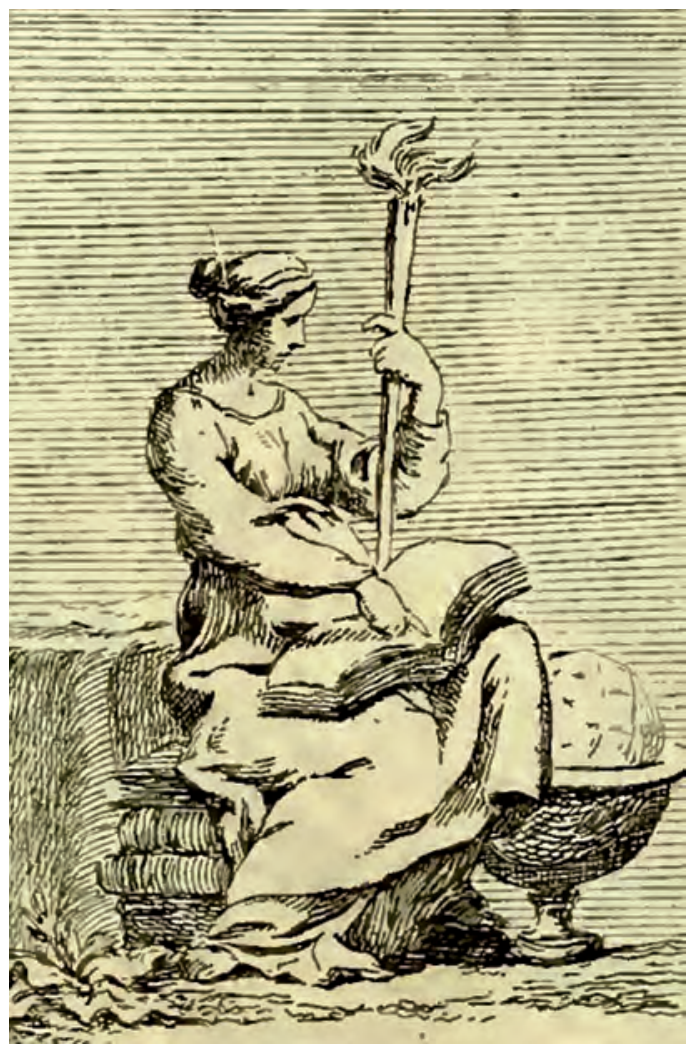




\section{LOS FANALES DEL NIÑO JESÚS Y LA CONSTRUCCIÓN SIMBÓLICA DE LA VIRTUD FEMENINA EN LOS MONASTERIOS DE CÓRDOBA DEL TUCUMÁN (FINES S. XVIII- COMIENZOS S. XIX)}

THE CHILD JESUS BELL JARS AND THE SYMBOLIC CONSTRUCTION OF FEMALE VIRTUE IN THE MONASTERIES OF CÓRDOBA DEL TUCUMÁN (LATE 18TH-EARLY 19TH CENTURY)

\section{Vanina SCOCCHERA}

http://doi.org/10.7203/arslonga.28.14375

Resumen: Se propone un estudio de los fanales del Niño Jesús en colecciones de la ciudad de Córdoba (Argentina) cuya procedencia de monasterios femeninos ha sido ampliamente documentada. Nuestra disciplina carece de investigaciones que lo aborden desde una perspectiva que responda a sus procesos de elaboración, seguidos de sucesivas manipulaciones, apropiaciones y resignificaciones simbólicas y materiales que atravesaron a lo largo de su vida. Se inicia un estudio cultural de la vida cotidiana desplegada en dichos monasterios femeninos para comprender las prácticas de creación de estos objetos, a la vez que se propone desarrollar un análisis iconográfico y material que nos permita comprender sus sentidos simbólicos, usos y funciones. El artículo aborda los imaginarios construidos en torno a la virtud femenina como una meta a la que las monjas debían aspirar en un camino de perfección y donde las prácticas contemplativas se entroncaron con las activas. Entre otras tareas se elaboraron fanales del Niño Jesús dotados de sentidos polisémicos y eficaces para recordar el destino asumido por estas monjas como mujeres virtuosas y sacrificiales.

Palabras clave: Fanales del Niño Jesús / monasterios femeninos / virtud femenina / Córdoba del Tucumán / fines siglo XVIII / inicios siglo XIX.
Abstract: This paper aims to develop a study of the Jesus Child bell jars existing at repositories of the city of Córdoba, Argentina, whose origin from female monasteries has been widely documented. However, our discipline lacks research that addresses the study of these devotional objects from a perspective that responds to the successive manipulations, appropriations, and symbolic and material resignifications. The present work intends to initiate a cultural study of the daily life cloisters linked to the practices of elaboration of Jesus Child bell jars. At the same time, it proposes to develop an iconographic and material analysis of its elements that allows us to understand their symbolic senses, uses and functions. We will approach the imaginaries constructed around the feminine virtue as a nun's goal. In the same way, we will analyze how the contemplative practices were connected with the active ones and they gave, as a result, the elaboration of Jesus Child bell jars. These significant objects had polysemous meanings effective to remember the destiny assumed by these nuns as virtuous and sacrificial women.

Key words: Jesus Child bell jars / femenin cloisters / femenin virtue / Córdoba del Tucumán / late 18th century / early 19th century.

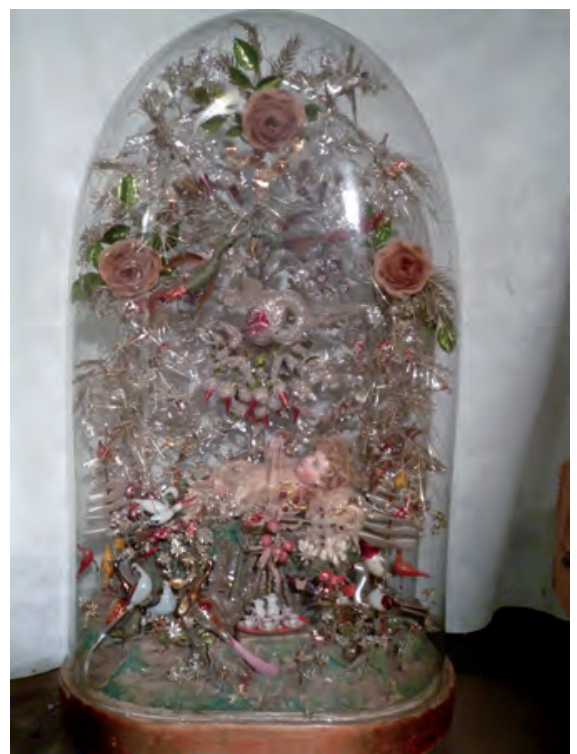




\title{
DE ARGENTINA AL MEDITERRÁNEO OCCIDENTAL. EL PLÁCIDO VIAJE DE MARIANO MONTESINOS
}

\author{
FROM ARGENTINA TO THE WESTERN MEDITERRANEAN. THE PLACID JOURNEY OF \\ MARIANO MONTESINOS
}

\section{Francisca LLADÓ POL}

http://doi.org/10.7203/arslonga.28.13771

Resumen: Este artículo pretende la recuperación del pintor argentino Mariano Montesinos en su paso por Mallorca (1925-1936). Se parte de la idea de insularidad dentro del enclave mediterráneo occidental ya que entre finales del siglo XIX y las primeras décadas del XX los conceptos de modernidad y clasicismo se hallaban intrínsecamente unidos. Ha sido necesario analizar los movimientos en boga que oscilaban entre el novecentismo italiano, el retorno al orden y el noucentisme. A partir de este último, se efectúa un estudio más exhaustivo, consecuencia de las relaciones entre Mallorca y Cataluña. Para comprender sus intereses se han tenido en cuenta las manifestaciones artísticas argentinas y los medios de difusión ligados al arte nuevo o martinfierrismo. El hecho de trabajar de forma comparativa permite recolocar las relaciones entre España y Argentina, tanto dentro de los circuitos del internacionalismo como para el reconocimiento de centros artísticos al margen de Madrid y Barcelona. El resultado es una producción ambivalente en el arte de Montesinos que nos permite asignarle un papel relevante en la modernidad que paulatinamente entraba en Mallorca, periodo que constituye la etapa más fructífera de su trayectoria.

Palabras clave: Mariano Montesinos / Mediterraneismo / Arte nuevo / Noucentisme / Retorno al orden / Martinfierrismo.
Abstract: The intention of this article is to recovery of the Argentine painter Mariano Montesinos during his stay in Mallorca (19251936). I have started from the idea of insularity within the Mediterranean enclave, moment in which the concepts of modernity and classicism were intrinsically linked. For this it has been necessary to analyze the movements in vogue that oscillated between the Italian Noucentisme, the return to order and the Noucentisme. It will be this last one that will allow a more exhaustive analysis of its productions as a result of the relations between Mallorca and Catalonia. However, to understand its position correctly, Argentine artistic manifestations and the media linked to the new art or Martinfierrismo have been taken into account. The fact of working in a comparative way allows to reestablish relations between Spain and Argentina, both within the circuits of internationalism and for the recognition of artistic centers outside of Madrid and Barcelona. Thanks to this study we find an ambivalent production in the art of Montesinos that allows us to place him in a relevant role of modernity without abandoning the medium in which he carried out the most fruitful stage of his career.

Key words: Mariano Montesinos / Mediterranism / New art / Noucentisme / Return to order / Martinfierrismo.

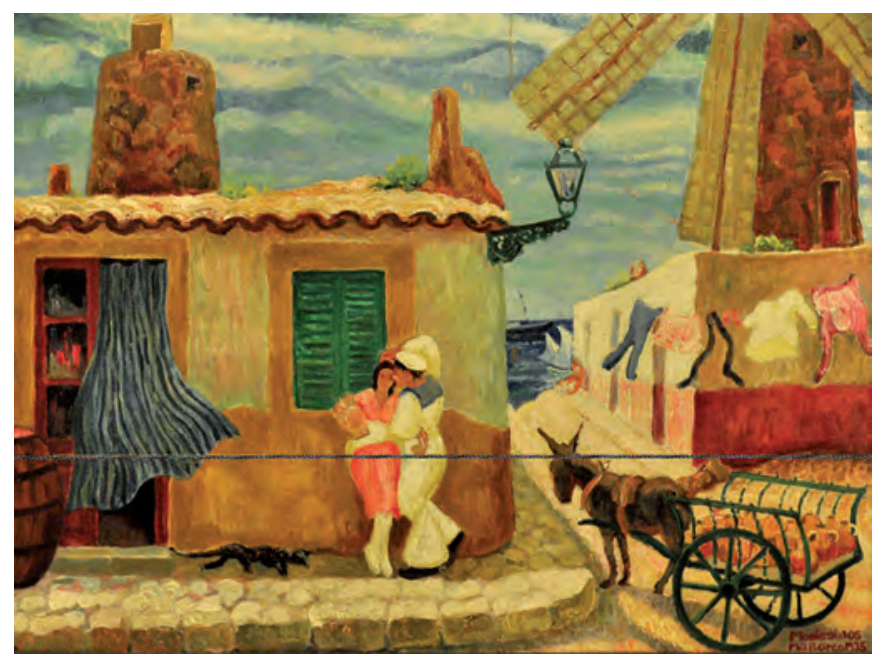




\section{BREVE RECORRIDO POR LOS CATÁLOGOS DE EXPOSICIONES RELACIONADAS CON PICASSO: 1900 - 2017}

BRIEF TOUR OF THE EXHIBITION CATALOGS RELATED TO PICASSO: 1900 - 2017

María ORTIZ TELLO

http://doi.org/10.7203/arslonga.28.14353

Resumen: El catálogo expositivo actúa como resultado y testigo de la exhibición afín, estableciéndose como un elemento clave para su investigación cuando ha sido clausurada. En la actualidad son auténticos libros de arte, que no solo dejan constancia de una exposición conjunta, sino que van más allá, ofreciendo auténticas investigaciones científicas. Pero no siempre fue así. Este tipo de publicación ha sufrido variaciones muy significativas a medida que transcurría el siglo XX. En este artículo se presenta un recorrido a través de su evolución, desde los primeros folletos hasta los grandes estudios actuales, tomando como ejemplo los catálogos de decenas de exposiciones que incluyen obras de Picasso, uno de los grandes artistas del siglo XX. De este modo, se expondrán las particularidades que han presentado los catálogos expositivos a lo largo de las décadas, y cómo han ido modificándose hasta alcanzar el grado de cientificidad actual.

Palabras clave: Picasso / Catálogos / Exposiciones / Occidente / Siglo XX.
Abstract: The exhibition catalog acts as a result and witness of the concomitant exhibition, establishing itself as a key element for its investigation when it has already been closed. Nowadays, the exhibition catalogs are authentic art books that not only show a joint exhibition, but go further, offering studies of authentic scientific nature. But it was not always like this. The exhibition catalog has undergone significant changes as the 20th century progressed. This article presents a journey through the evolution of the exhibition catalog, from the first bro-chures to the current great studies, taking as an example one of the great artists of the 20th century, Pablo Ruiz Picasso, and the catalogs of dozens of exhibitions in which his work was exposed. In this way, we will see what particularities the exhibition catalogs have been showing over the decades and how they have been modified until reaching the current degree of scientificity.

Key words: Picasso / Catalogs / Exhibitions / The West / Twentieth Century.

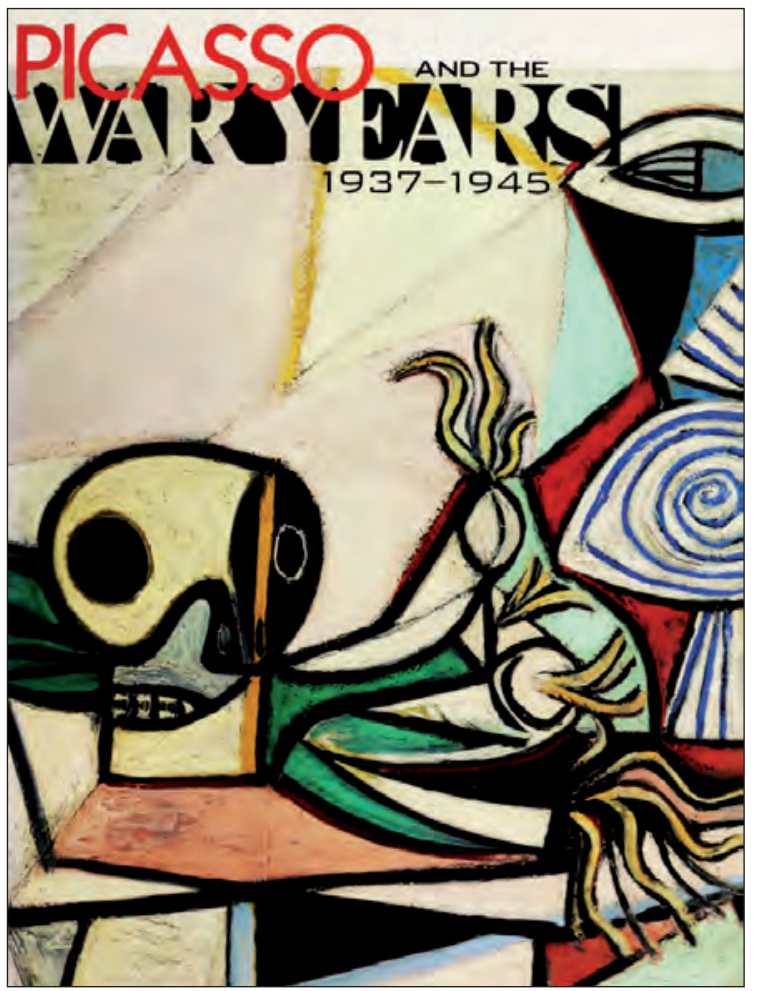


ESTUDIO DE UNA PEQUEÑA Y DESCONOCIDA COLECCIÓN: LOS KYÔDO-GANGU DE JOAN MIRÓ

\section{STUDY OF A SMALL AND UNKNOWN COLLECTION: JOAN MIRÓ'S KYÔDO-GANGU}

\section{Muriel GÓMEZ PRADAS}

http://doi.org/10.7203/arslonga.28.14387

Resumen: Este artículo aborda el estudio de unos singulares objetos japoneses que Joan Miró atesoró tanto en su taller como en su residencia mallorquina. Se trata de unos kyôdo-gangu o juguetes tradicionales y populares japoneses, unos objetos de pequeño tamaño, que tanto pueden ser figuras antropomorfas como zoomorfas, de materiales sencillos y cotidianos, de carácter tradicional y de consumo popular y que solían tener usos y significados muy variados. El objetivo de este artículo es trazar la biografía de estos objetos, analizando su simbología, procedencia y uso social, e intentando establecer cómo llegaron a manos del artista.

Palabras clave: kyôdo-gangu / Joan Miró / Japón / coleccionismo / uso social.
Abstract: This article is focused on the analysis of some singular Japanese objects that Joan Miró treasured, both in his workshop and in his Majorcan residence. These singular objects are kyôdogangu or Japanese Folk Toys, which can be either anthropomorphic or zoomorphic figures. They are made of simple and everyday materials, of a traditional nature and popular consumption and which used to have diverse meanings and uses. The aim of this article is to trace their biography, by analyzing their symbology, origin and social use, and try to determine how they arrived to the artist's hands.

Key words: kyôdo-gangu / Joan Miró / Japan / collecting / social use. 
INTELLECTUAL ART AT THE VENICE BIENNALE: UKRAINIAN COMPONENT

EL ARTE INTELECTUAL EN LA BIENAL DE VENECIA: COMPONENTE UCRANIANO

\section{Oleksii ROHOTCHENKO}

http://doi.org/10.7203/arslonga.28.14349

Resumen: Uno de los foros artísticos más prestigiosos del mundo fue y sigue siendo el de la Bienal de Venecia. A lo largo de ciento veintitrés años, los principios democráticos han liderado procesos artísticos en la costa de la ciudad fantástica. El lema: "Mostrar lo nuevo" sigue vivo, empujando a los artistas a mostrar el arte contemporáneo o el más avanzado de los países participantes. Arsenal y Giardini son dos de las carreras artísticas más grandes, así como cientos de callejones, iglesias y galerías en Venecia, donde durante dos años hay otra bienal, donde artistas y comisarios de todo el planeta compiten para el León de Oro, el principal premio de la exposición. La Bienal de Venecia es un fenómeno absolutamente único en el sistema de coordenadas de las bellas artes. En la muestra de obras, que dura medio año, existe su propio patrón y su propia intriga. Además de presentar las innovaciones culturales de los países participantes, se identifican líderes artísticos explícitos y está surgiendo la tendencia principal en arte contemporáneo para los próximos dos años. En el artículo propuesto, discutiremos la participación de Ucrania en la Bienal de Venecia. Este texto cubre la opinión del autor sobre los problemas de la participación de los artistas ucranianos en la bienal.

Palabras clave: Bienal de Venecia / artista / arte / comisario / proyecto / arsenal.
Abstract: The Venice Biennale has always been and remains one of the most prestigious art forums in the world. Throughout the whole one hundred and twenty-three years, democratic principles were the driving force for artistic processes, constantly in full swing in this fantastic coastal city. The motto "Show new" is alive as ever, urging artists to present the contemporary or the most advanced art of the participating countries. Every two years competing artists and curators from all over the world exhibit their pieces at the Arsenal and Giardini (the largest venues), as well as at the hundreds of villas, churches, and galleries scattered around Venice, engaging in an art competition for the top prize -the Golden Lion. The Venice Biennale is an absolutely unique phenomenon within the artistic system of coordinates. The works are on display for half a year, building up regularity and adding intrigue to the show. Besides the presentation of cultural innovations, the clear leaders and trends in contemporary art are determined for the next two years. Ukrainian participation in the Venice Biennale is discussed in the article. The text covers the author's view on the problems of participation of Ukrainian artists in the Biennale.

Key words: Venice Biennale / Artist / Art / Curator / Project / Arsenal. 


\section{EL DEPARTAMENT D'HISTÒRIA DE L'ART DE LA UNIVERSITAT DE VALÈNCIA EN EL CURSO 2018-2019}

THE ART HISTORY DEPARTAMENT OF THE UNIVERSITY OF VALENCIA DURING THE ACADEMIC YEAR 2018-2019

\section{Departament d'Història de l'Art}

http://doi.org/10.7203/arslonga.28.16819

Resumen: En el presente texto-memoria se enumeran los aspectos docentes más destacados relacionados con el Departament d'Història de l'Art de la Universitat de València en el curso académico 2018-2019, así como las contribuciones investigadoras de sus miembros en el año 2018 y otros aspectos de interés relacionados con la difusión y gestión del citado departamento universitario.

Palabras clave: Enseñanza Universitaria en España / Investigación / Historia del Arte / Departament d'Història de l'Art de la Universitat de València.
Abstract: In this section, the most remarkable educational aspects in connection with the Art History Department of the University of Valencia during the academic year 2018-2019 are enumerated, along with the research contributions of its members throughout 2018 and other aspects of interest concerning the diffusion, the management and other important activities of this University Department.

Key words: University Education in Spain / Research / History of Art / Art History Department of the University of Valencia.

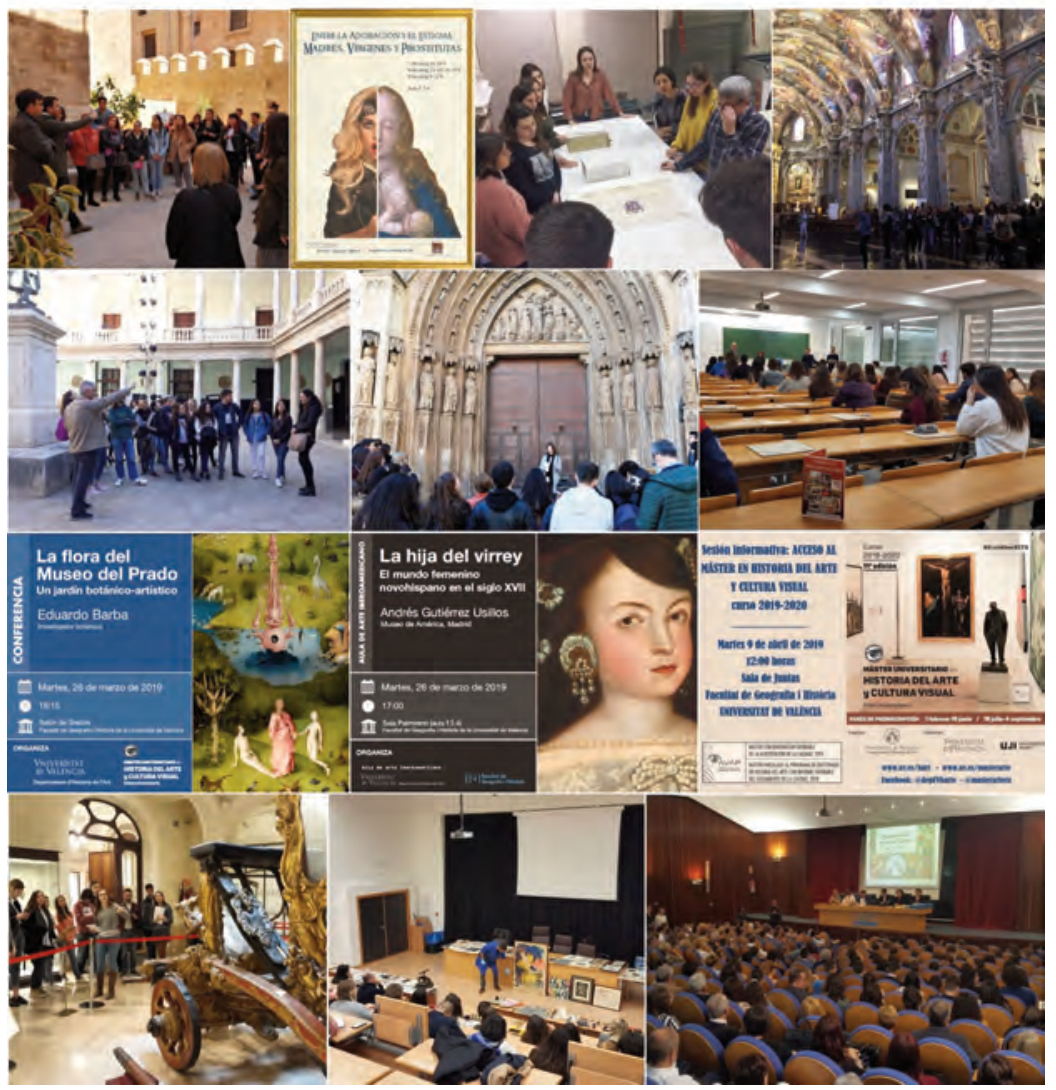


XESQUI CASTAÑER LÓPEZ. SEMBLANZAS ACADÉMICAS

XESQUI CASTAÑER LÓPEZ. ACADEMIC SEMBLANCES

Nuria RODRÍGUEZ ORTEGA // María Eugenia ROJO MAS

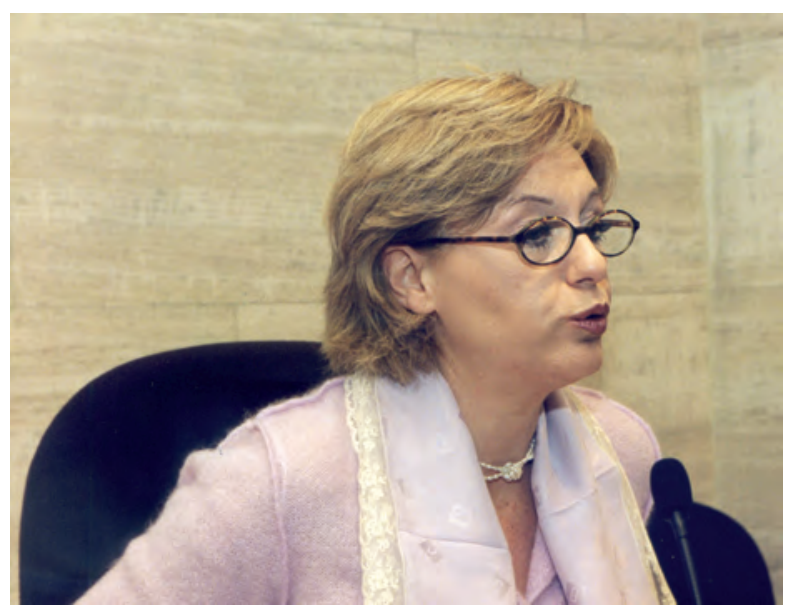

LA COMPRA DIRECTA DE OBRAS DE ARTISTAS VASCOS CONTEMPORÁNEOS POR LOS MUSEOS PÚBLICOS DEL PAÍS VASCO Y EL IMPACTO SOBRE EL PRECIO DE SUS OBRAS EN LAS SUBASTAS DE ARTE: 1985-2017

THE IMPACT OF SPANISH BASQUE MUSEUMS' DIRECT PURCHASES ON AUCTION PRICES OF MODERN AND CONTEMPORARY BASQUE ARTWORKS, 1985-2017

Xesqui CASTAÑER LÓPEZ (†) \& José Luis HERNÁNDEZ MARCO

RECENSIONES DE LIBROS / BOOK REVIEWS

ACEPTACIÓN DE ORIGINALES Y PROCESO DE EDICIÓN NOTES FOR CONTRIBUTORS AND PUBLICATION GUIDELINES 
